'Servicio de Infectología, Hospital Militar de Santiago. Santiago, Chile.

2Programa Formación Medicina Interna, Facultad de Medicina. Sede Hospital Militar de Santiago. Universidad de Valparaíso. Valparaíso, Chile.

${ }^{3}$ Escuela de Medicina, Universidad de los Andes. Santiago, Chile.

4Programa Formación Medicina Interna, Escuela de Medicina, sede Hospital Militar de Santiago. Escuela de Medicina, Universidad de los Andes. Santiago, Chile. ${ }^{5}$ Servicio de Anatomía Patológica, Hospital Militar de Santiago. Santiago, Chile. Interna de la carrera de Medicina.

Conflicto de Interés: ninguno. Financiamiento: ninguno.

Recibido el 29 julio de 2018, aceptado el 31 de enero de

Correspondencia a: Dr. Alberto Fica Médico Infectólogo, Subdepartamento de Medicina, Hospital Base de Valdivia. Bueras 1003, Valdivia, Región de Los Ríos, Chile. albertoficacubillos@gmail.com

\section{Fatal nosocomial hemorrhagic enterocolitis probably caused by adenovirus. Report of one case}

\author{
ALBERTO FICA $^{1}$, PABLA CATALDO ${ }^{2}$, DIANA ACEITUNO ${ }^{3, a}$, \\ MARÍA IGNACIA VILLARROEL ${ }^{4}$, ARTURO ESCALONA ${ }^{5}$
}

\begin{abstract}
Adenovirus $(A D V)$ is a recognized cause of severe disease among immunocompromised patients. We report a previously healthy 39-year-old female, admitted with influenza pneumonia and evolving with lung hemorrhage and acute renal failure requiring mechanical ventilation and hemodialysis. She received high corticosteroid doses due to an initial suspicion of alveolar hemorrhage. Lymphopenia already present before steroid use $(567 / \mu L)$, was maintained during the whole hospital stay (mean 782/ $\mu \mathrm{L}$ ). From the second week of admission she presented a high-volume diarrhea (mean $2.5 \mathrm{~L} /$ day) associated to intermittent bloody stools. An ulcerative enterocolitis was confirmed by CT images and colonoscopy. ADV was detected in a colonic tissue sample by real time PCR but not by a commercial filmarray test. Cidofovir-probenecid and racecadotril therapy were indicated without changing the clinical course of diarrhea and the patient finally died.
\end{abstract}

(Rev Med Chile 2019; 147: 256-260)

Key words: Acute Kidney Injury; Adenoviridae; Adrenal Cortex Hormones; Cross Infection; Enterocolitis.

\section{Enterocolitis hemorrágica fatal nosocomial probablemente causada por adenovirus. Informe de un caso}

Adenovirus ( $A D V)$ es una causa reconocida de enfermedades graves en pacientes inmunocomprometidos. Informamos el caso de una mujer de 39 años, previamente sana, que ingresó por neumonía grave por influenza, evolucionando con hemorragia pulmonar y falla renal aguda, requiriendo ventilación mecánica $y$ hemodiálisis. Recibió altas dosis de corticoides por la sospecha inicial de una hemorragia alveolar. Tuvo linfopenia durante toda su estadía (promedio 782/ $\mu L)$, la que ya estaba presente antes del uso de los corticoides (567/ $\mu L)$. Desde la segunda semana de hospitalización, presentó una diarrea de alto volumen (promedio 2,5 L/día) asociada a la presencia de sangre en deposiciones en forma intermitente. Se confirmó una enterocolitis ulcerativa por tomografía computada y colonoscopía. Se detectó ADV en muestras de biopsia colónica por PCR en tiempo real pero no por un test de PCR múltiples automatizado comercial. Fue tratada con cidofovir-probenecid y racecadrotrilo sin impacto clínico y la paciente finalmente falleció.

Palabras clave: Lesión renal aguda; Corticoesteroides; Enterocolitis. 
A denoviridae (ADV) infections are important among immunocompromised adults or children with solid organ or bone marrow transplantation, AIDS, cancer or congenital immune defects ${ }^{1,2}$. In these patients, ADV infection can provoke pneumonia, hepatitis, hemorrhagic cystitis, enterocolitis or a disseminated presentation, sometimes with a fatal outcome ${ }^{1-4}$. ADV infections are associated to different serotypes or hexon sequence genotypes and can appear as sporadic disease or outbreaks ${ }^{5,6}$. Transmission occurs by fecal-oral route, droplets or fomites and sometimes in healthcare settings. Severe disease has been linked to chronic conditions, early childhood, recent transplantation and with ADV types ${ }^{6}$. We report a healthcare acquired, severe and fatal case of enterocolitis secondary to ADV infection in a previously healthy woman admitted by influenza that appeared after acute renal failure, persistent lymphopenia, and high corticoids doses.

\section{Case report}

A 39-year-old female was admitted by pandemic influenza AH1N1 pneumonia. She rapidly evolved with respiratory insufficiency and shock, requiring mechanical ventilation and received empirical therapy with ceftriaxone, levofloxacin and oseltamivir. Other infectious agents were discarded by blood cultures, urinary antigens, serology and complementary search of other respiratory viruses by PCR. Hemodialysis was initiated as she presented acute renal failure secondary to glomerulonephritis (hematuria, proteinuria and hypocomplementemia) (Figure 1). Because alveolar hemorrhage was suspected by the presence of hemoptysis, methylprednisolone (MP) was indicated during 3 days, totaling 3 grams (Figure 1). Diagnosis was discarded by negative hemosiderin-loaded macrophages and negative immunological studies.

Patient evolved stable but developed profuse watery diarrhea since the $14^{\text {th }}$ day (mean $2.5 \mathrm{~L} /$ day). A study using the molecular Film array ${ }^{\circledR}$ GI panel (Biomerieux) able to detect Campylobacter, Clostridium difficile, Plesiomonas shigelloides, Salmonella, Yersinia enterocolitica, Vibrio, diarrheogenic E. coli/Shigella, Cryptosporidium, Cyclospora cayetanensis, Entamoeba histolytica, Giardia lamblia, adenovirus F40/41, astrovirus, norovirus, rotavirus $\mathrm{A}$, and sapovirus, showed no agents. Because hemorrhagic stools appeared on the $17^{\text {th }}$ day, a colonoscopy was performed showing an ulcerative pancolitis. Biopsy demonstrated ulcers and infiltration of inflammatory cells of mononuclear predominance. Possible smudged cells were detected. Imaging studies obtained by a CT scan indicated diffuse parietal enlargement in both the small and large intestine but not other abnormalities (not shown). Initiation of bloody stools was in parallel to a mild thrombocytopenia $(124,000$ to $87,000 / \mu \mathrm{L})$. Due to the high suspicion of gastrointestinal cytomegalovirus (CMV) disease, gancyclovir was prescribed but finally suspended after 7 days when a laboratory report showed a low CMV viral load on a blood sample $(<1,000$ copies $/ \mathrm{mL})$ and immunohistochemical stains for CMV and herpes virus simplex 1-2 on the colonic biopsy were also negative.

Expanding the etiological study of her protracted diarrhea, adenovirus was searched on the colonic biopsy sample and confirmed by a commercial kit (Adenovirus R-gene; Biomerieux ${ }^{\circledR}$ ). After the diagnosis of ADV enterocolitis, cidofovir (325 $\mathrm{mg} /$ week) with probenecid was initiated (Figure 1), however, clinical response to this therapy was uncertain due to the cyclical course of the diarrhea (Figure 1) and control CT images revealed persistence of the concentric enlargement of the small and large intestine (Figure 2). Partial or totally hemorrhagic stools were registered during 17 of the 62 days of hospitalization (27\% of the period, Figure 1). Diarrhea was managed using supportive measures with electrolyte and fluid reposition and also with racecadotril that did not alter fluid losses (Figure 1). In addition, red blood cell transfusions were needed 9 times due to anemia secondary to hemorrhagic enterocolitis.

The patient presented new complications including septic shock, bacteremia, bronchopleural fistula, pneumothorax and pneumonia secondary to Pseudomonas aeruginosa that required a chest tube, reconnection to mechanical ventilation and antibiotic therapy. During the last days of her fatal evolution she presented upper gastrointestinal bleeding, bloody diarrhea, consumption coagulopathy, and a new episode of acute renal failure that required again hemodialysis and transfusions. An upper endoscopy performed at the $49^{\text {th }}$ day showed active ulcers at the jejunum and also an ulcer in the distal part of the esophagus, both with 


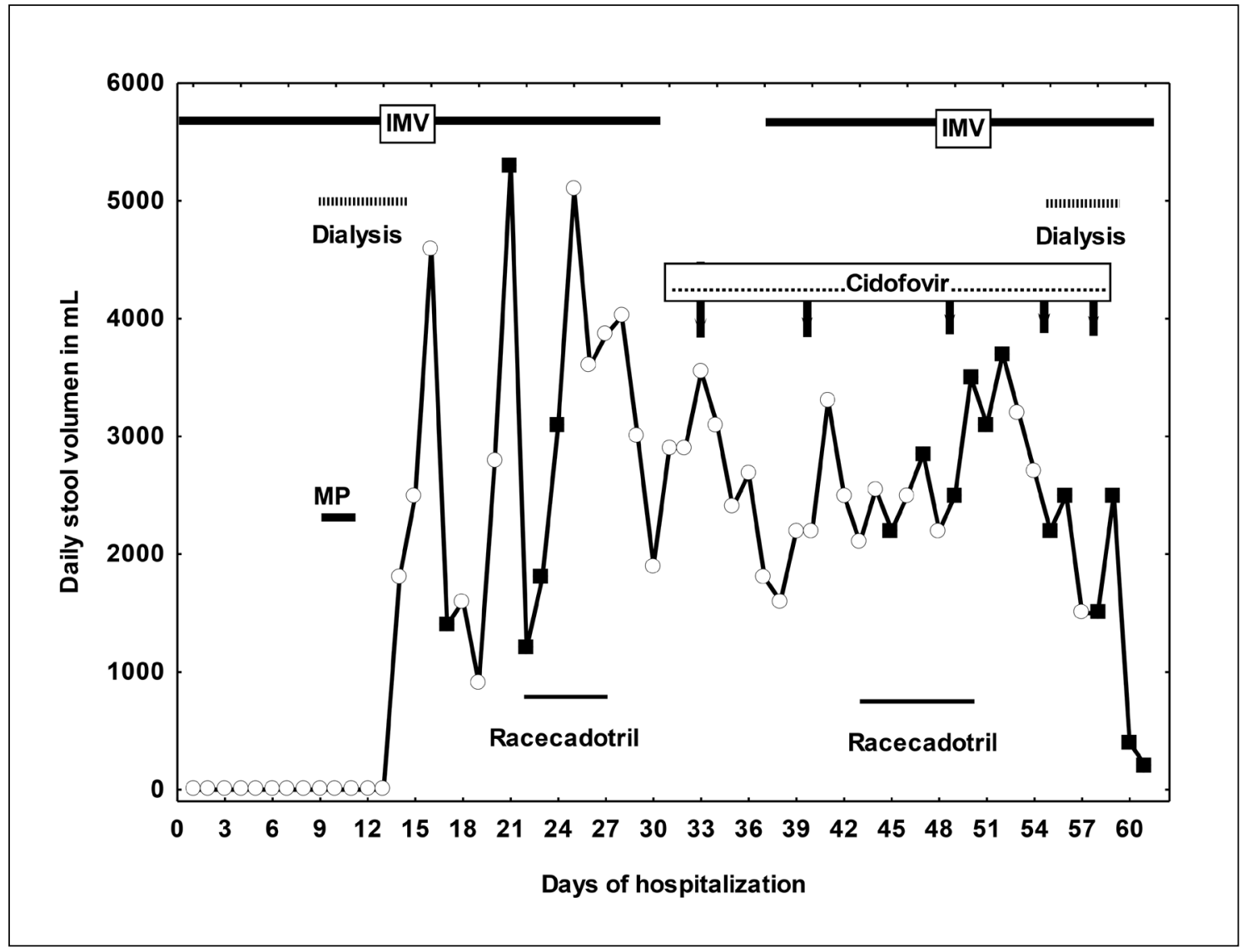

Figure 1. Landmarks during the evolution of a patient affected by adenovirus enterocolitis. IMV and related bars indicate period with invasive mechanical ventilation. Methyl predinosolone bolus are indicated by MP and the related bar. Black squares show days when bloody stools were registered. Open circles indicate days with watery diarrhea. Racecadotril therapy (from $22^{\text {nd }}$ to $27^{\text {th }}$ and then from the $43^{\text {rd }}$ to $50^{\text {th }}$ days of hospitalization) is also indicated in the Figure.

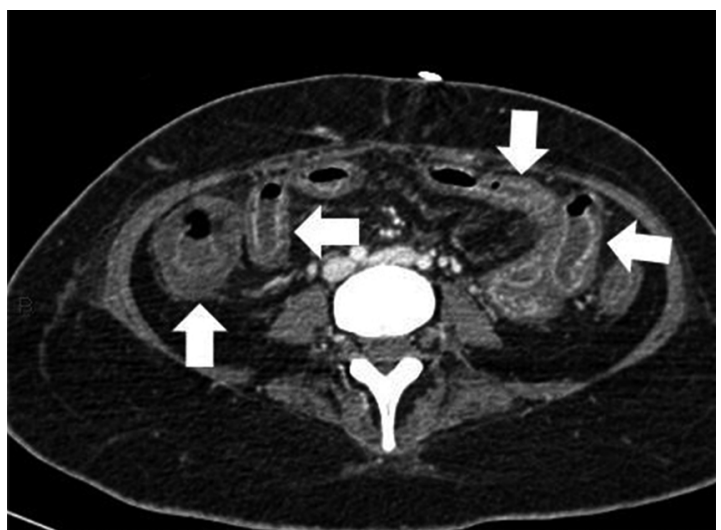

Figure 2. Abdominal CT scan with contrast media showing parietal enlargement of the large and small intestine (arrows). active bleeding. A parallel colonoscopy indicated persistence of ulcers with bleeding. Biopsies of the upper gastrointestinal tract revealed ulcers and infiltration by inflammatory cells, and necrotic material on the colonic sample. PCR did not show at this time adenoviral genetic material.

Lymphocyte count was low during the whole stay of the patient (mean 782 per $\mu \mathrm{L}$; range 1621484) and was already present at admission (567/ $\mu \mathrm{L})$. The average lymphocyte count during the 8 days from admission and before MP was 853 per $\mu \mathrm{L}$ (range 566-1056). This value decreased to $654 / \mu \mathrm{L}$ during the 8 days following MP doses (range 360-848) although did not reach statistical significance. 


\section{Discussion}

This case underlines the wide clinical range of immunocompromised patients that can be affected by an ADV infection. The classical list includes patients with AIDS, solid organ or bone marrow transplantation, cancer or congenital immune deficiencies. In our case, high corticosteroid doses and acute renal failure, likely provoked a hemorrhagic enterocolitis by this agent. Both can affect the immune system and favor opportunistic infections $s^{7-10}$. Lymphopenia could have potentiated the immune disarrangement provoked by renal injury and steroid use, being an important risk factor for developing ADV viremia among pediatric stem-cell recipients. Failure to recover or increase its absolute number is associated with a fatal outcome ${ }^{11,12}$. We believe that corticosteroids in high doses, acute renal failure and a persistent lymphopenia in our patient conjugated to provoke an ADV infection of prolonged and fatal course.

Enterocolitis secondary to ADV infection appears to be well supported in our case: diarrhea, inflammatory compromise with ulcers and bleeding both at the small and large intestine (demonstrated either by CT images or endoscopic studies), and biopsies with detection of ADV together with negative studies for other causes. ADV infection has been rarely reported among immunocompromised patients without the classical factors commented above. One patient developed a disseminated disease while being treated by steroid for systemic lupus erythematosus and other patient with rheumatoid arthritis suffered from ADV pneumonia after steroid and anti-TNFtherapy, but none of them with gastrointestinal compromise $\mathrm{c}^{13,14}$.

Management of this patient was extremely difficult due the high volume of diarrhea, its prolonged course, associated hemorrhage and unresponsiveness to different therapies. Blood transfusion, and electrolyte and fluid reposition allowed maintaining her alive for several weeks. However, cidofovir and racecadotril therapy did not have impact on the clinical course of her evolution.

A healthcare transmission was feasible in this case as 2 patients with severe acute respiratory infection (SARI) secondary to ADV were admitted to the ICU the same week that the patient initiated diarrhea but not the following or the preceding 5 weeks (information obtained from surveillance databases of the hospital). On the other hand, endogenous reactivation from intestinal lymphoid tissues has been reported among children undergoing hematopoietic stem cell transplantation being a possible mechanism in our case that cannot be totally discarded ${ }^{1,15}$. Unfortunately, no molecular comparisons were made to help elucidate the most probable origin of the ADV infection. Hospital-acquired ADV infections are well known in pediatric or immunosuppressed settings but mostly described as eye or respiratory illnesses. In any case, our case reinforce the wide clinical range of ADV complications among immunosuppressed patients.

Diagnosis of ADV infection can be attempted by viral culture, direct antigen detection, qualitative or quantitative PCR, electron microscopy or immunohistochemical detection, and depends on the available sample, lab access and purpose of the study ${ }^{1}$. In addition, the diagnosis can be suggested by detection of smudge cells on tissular samples, characterized by enlarged nuclei with basophilic inclusions and surrounded by a thin rim of cytoplasm $^{1,4}$. The FilmArray GI panel (Biomerieux ${ }^{\circledR}$ ) did not detect ADV on stool samples in our patient but this fact was not surprising due to the restricted ADV repertoire of this technique able only to detect serotypes 40 and 41 of the ADV species $\mathrm{F}^{16}$. In contrast, diagnosis was possible using a molecular method targeted to conserved ADV sequences (Adenovirus R-gene; Biomerieux ${ }^{\circledR}$ ) that has shown elevated sensitivity and specificity in respiratory samples ${ }^{17}$. Thus, appropriate knowledge of the limitations and advantages of modern technology is crucial to pursue the diagnosis when suspicious is high.

Several compounds have been evaluated in immunocompromised patients with ADV infection. Among them, cidofovir-probenecid has received more attention with an evaluation of its impact available through observational studies ${ }^{1,18,19}$. Among stem cell transplant recipient, case-fatality ratio with cidofovir therapy ranges between 19\% and $>50 \%$ and survival depends on immune reconstitution and treatment precocity, none of them acting in our patient ${ }^{1,18,19}$.

Probenecid is prescribed along with cidofovir therapy both to enhance plasmatic concentration of the antiviral drug during the first weeks and to simultaneously protect kidney from toxicity ${ }^{20}$. 
In conclusion, our patient illustrates the wide range of immunocompromised patients that can evolve with an ADV infection. Persistent lymphopenia, acute renal injury and high corticosteroid doses favored ADV disease in a previously immune competent patient. ADV disease was acquired during hospitalization, evolved with a protracted aqueous and hemorrhagic enterocolitis, was unresponsiveness to antiviral therapy and had a fatal outcome. Diagnosis required molecular techniques applied to tissular samples targeting ADV conserved sequences but failed when was attempted using a commercial panel.

\section{References}

1. Echavarría M. Adenovirus in immunocompromised hosts. Clin Microbiol Rev 2008; 21 (4): 704-15.

2. Pham TT, Burchette JL Jr, Hale LP. Fatal disseminated adenovirus infections in immunocompromised patients. Am J Clin Pathol 2003; 120 (4): 575-83.

3. Symeonidis N, Jakubowski A, Pierre-Louis L, Jaffe D, Pamer E, O’Reilly RJ, Papanicolaou GA.. Invasive adenoviral infections in T-cell-depleted allogeneic hematopoietic stem cell transplantation: high mortality in the era of cidofovir. Transpl Infect Dis 2007; 9 (2): 108-13.

4. Abarca K, Le Corre N, Perret C, Wietstruck A, Oddó D, Barriga F. [Disseminated and fatal adenovirus infection in an immunocompromised child]. Rev Chilena Infectol 2008; 25 (2): 127-32.

5. Cassir N, Hraiech S, Nougairede A, Zandotti C, Fournier PE, Papazian L. Outbreak of adenovirus type 1 severe pneumonia in a French intensive care unit, SeptemberOctober 2012. Euro Surveill 2014;19 (39).pii: 20914.

6. Gray GC, McCarthy T, Lebeck MG, Schnurr DP, Russell KL, Kajon AE, et al. Genotype prevalence and risk factors for severe clinical adenovirus infection, United States 2004-2006. Clin Infect Dis 2007; 45 (9): 1120-31.

7. Lessof MH. Immunodeficiency states. Proc R Soc Med 1974; 67 (6 Pt 2): 530-6.

8. Cohen G, Hörl WH. Immune dysfunction in uremia-An update. Toxins 2012; 4 (11): 962-90.

9. Druml W. Systemic consequences of acute kidney injury. Curr Opin Crit Care 2014; 20 (6): 613-9.

10. Poekter DM, Reh DD. A comprehensive review of the adverse effects of systemic corticosteroids. Otolaryngol Clin North Am 2010; 43 (4): 753-68.

11. Heemskerk B, Lankester AC, van Vreeswijk T, Beersma MF, Class EC, Veltrop-Duits LA, et al. Immune reconstitution and clearance of human adenovirus viremia in pediatric stem-cell recipients. J Infect Dis 2005; 191 (4): 520-30.

12. Chakrabarti S, Mautner V, Osman H, Collingham KE, Fegan CD, Klapper PE, et al. Adenovirus infections following allogeneic stem cell transplantation: incidence and outcome in relation to graft manipulation, immunosuppression, and immune recovery. Blood 2002; 100 (5): 1619-27.

13. Kajon AE, Dickson LM, Fisher BT, Hodinka RL. Fatal disseminated adenovirus infection in a young adult with systemic lupus erythematosus. J Clin Virol 2011; 50 (1): 80-3.

14. Kang MJ, Kim MS, Choi EH, Lee KE, Kim YK, Choi HJ. Adenoviral pneumonia during etarnecept treatment in a patient with rheumatoid arthritis. Korean J Intern Med 2007; 22 (1): 63-6.

15. Kosulin K, Geiger E, Vécsei A, Huber WD, Rauch M, Brenner E, et al. Persistence and reactivation of human adenoviruses in the gastrointestinal tract. Clin Microbiol Infect 2016; 22: 381.e1-e8.

16. Buss SN, Leber A, Chapin K, Fey PD, Bankowski MJ, Jones $\mathrm{MK}$, et al. Multicenter evaluation of the Biofire FilmArray gastrointestinal panel for etiologic diagnosis of infectious gastroenteritis. J Clin Microbiol 2015; 53 (3): 915-25.

17. Manji R, Zheng X, Patel A, Kowerska M, Vossinas M, Drain A, et al. Multi-center evaluation of the adenovirus R-gene US assay for the detection of adenovirus in respiratory samples. J Clin Virol 2014; 60 (2): 90-5.

18. Lindemans CA, Leen AM, Boelens JJ. How I treat adenovirus in hematopoietic stem cell transplant recipients. Blood 2010; 116 (25): 5476-85.

19. Neofytos D, Ojha A, Mookerjee B, Wagner J, Filicko J, Ferber A, et al. Treatment of adenovirus disease in stem cell transplant recipients with cidofovir. Biol Blood Marrow 2007; 13 (1): 74-81.

20. Lacy SA, Hitchcock MJ, Lee WA, Tellier P, Cundy KC. Effect of oral probenecid coadministration on the chronic toxicity and pharmacokinetic of intravenous cidofovir in cynomolgus monkeys. Toxicol Sci 1998; 44 (2): 97-106. 